Juha-Matti Lehtonen, Professor, Defence Acquisition, Department of Military Technology, National Defence University, Finland; juha-matti.lehtonen@mil.fi Henry Isojärvi, Senior Lieutnant, Finnish Air Force; henry.isojarvi@mil.fi

\title{
Nordic Armaments Co-operation Savings Potential
}

\section{Keywords}

Defence co-operation, NORDEFCO, procurement, maintenance, armaments, savings

\begin{abstract}
The purpose of this paper is to estimate the potential cost savings of Nordic defence co-operation, which is frequently given as one of the arguments in its favour by politicians. Theoretical grounds for savings in co-operation such as economies of scale are reviewed in both the business and defence contexts. Then the potential cost savings in the future acquisition plans are studied through comparing countries' plans and in maintenance through assessing the commonality of current military equipment. Comparison of public defence purchasing plans reveals that the opportunities for procurement co-operation are limited as Nordic countries are planning to acquire mainly different equipment. Due to differences in current military equipment, the savings opportunities in maintenance are likewise limited other than in the land vehicles' sector. As currently practiced, Nordic defence co-operation seems not to offer any savings potential that could make a difference at the overall military budget level. The independent assessment of this article is based on publicly available data, which limits both the scope and details of the results.
\end{abstract}

\section{Introduction}

Ever since the end of the cold war, the defence budgets in the countries of Europe have been in decline, and the recent era of austerity has certainly not changed the trend. Compared to the formidable economic clout of Europe, in the military sphere it is viewed as an underperformer, especially in comparison to the USA. According to the European Commission (2015), the fragmentation of European defence markets leads to the unnecessary duplication of capabilities, organisations and expenditures and, as a result, the industry is lacking the necessary economies of scale. Similar arguments are also present in Nordic discussions. Between the 
Nordic countries, Nordic Defence Co-operation (NORDEFCO) was established in 2009, having been preceded by various co-operation areas, including the Nordic armaments co-operation (NORDAC) of the 1990s.

A recent Swedish inquiry on defence co-operation concludes that technological development, changes in modern warfare, cost increases and the financial pressure of shrinking budgets make the efforts to maintain a traditional range of capabilities alone increasingly difficult, thereby necessitating international co-operation (Bertlman \& Anclair, 2013). According to Saxi (2011), in the late 2000s there was an intensification of Nordic co-operation leading to the founding of NORDEFCO, of which the main driver was economic: the shrinking budgets, rising costs and international missions. As the motivation for co-operation, both Finnish and Swedish official documents regarding NORDEFCO emphasise better security in a regional context as well as better use of resources and cost-efficiency in defencerelated areas. An analysis of Finnish defence ministers' fifty-four official speeches during the past six years by one of the authors shows that cost-efficiency is the most often cited argument for Finland's interests in NORDEFCO; Nordic defence co-operation was mentioned in twenty speeches and, of those, cost-efficiency was used as an argument in nine speeches. Norwegian minister of defence Søreide (2014) pointed out one overarching goal for Norway's year as chair of NORDEFCO: the need for improved cost-efficiency and increased operational effect, which also includes developing a close dialogue between NORDEFCO and the defence industry and continued that "The desired end result must be greater effect - either operational or economic."

According to Valášek (2011), decisions on how to co-operate and with whom should be rooted in a rigorous cost and benefit analysis, along with a thorough public discussion of their industrial and political impact. Even though all nations emphasise cost-efficiency as one of the most important goals in Nordic defense cooperation, the politicians do not back up their words in public with any kind of calculations. No official public document can really present calculations whereby Nordic countries can find more value-for-money. About the only public calculation with savings figures is in the pages of NORDEFCO, which estimates $100 \mathrm{M} €$ cost savings in common development, purchasing and maintenance of defence materiel during a fifteen-year period (NORDEFCO, 2015a). At face value, the figure is substantial, but it translates to a comparatively insignificant $1.67 \mathrm{M} €$ per year per country - hardly anything to show for the effort. A Swedish Ministry of Defence report by Bertelman and Anclair (2013) admits that there has been a gap between the rhetoric and concrete action and in order to achieve any real economic impact, 
Nordic co-operation would require difficult political choices and sometimes a willingness to sacrifice the country's own national interests.

This mismatch between political talk, ambitions and achievement that can be demonstrated with concrete figures translates to the objective of this paper, which is to establish an estimate of the potential cost savings of Nordic defence cooperation. Could Nordic defence co-operation bring substantial economic benefits that would merit the considerable political interest and through which more substantial savings could perhaps be found? Even though co-operation can come about in many areas, such as training and exercises, the scope in this paper is limited to the potential for savings in materiel co-operation including both procurement and life-cycle support; the area that in NORDEFCO is called armaments co-operation.

The paper starts by reviewing the situation in each Nordic country (except Iceland, which doesn't have defence forces) and then takes a closer look at the defence budgets and their contents. Theoretical grounds for savings in co-operation such as economies of scale are reviewed in both the business and defence contexts. Then opportunity in the acquisition plans and maintenance is studied through comparing countries' plans and existing equipment, respectively. Finally, the savings potential is estimated and discussed. The paper ends with a conclusion, the limitations and an outlook for further research.

\section{Defence Tasks and Resources in the Nordic Countries}

In terms of international institution membership choices, the Nordic countries are different. Norway and Denmark are NATO members, while Sweden and Finland are militarily non-aligned i.e. not participating in military alliances. Norway is not an EU-member while the three others are. Denmark, with its opt-out of EU defence, is the only EU country not participating in the European Defence Agency (EDA), while Norway has an administrative agreement with the EDA.

If one looks up the stated tasks of the defence forces of four Nordic countries (Försvarsmakten 2015, Forsvaret 2015a, Forsvaret 2015b, The Finnish Defence Forces 2015), one finds similarities, although wordings and definitions differ. The armed defence of the nation's territory is mentioned by all countries. In addition, NATO members Norway and Denmark recognise the importance of the alliance and the obligation of members to participate in collective defence. Sweden and Norway specifically mention surveillance as a separate task - and Sweden 
mentions that task even before armed defence - while in Finland it is just a part of the territorial defence. In Denmark, territorial defence has a small role in the Danish defence agreement (2012) as defence forces "must be able to participate in the full range of international missions" while national tasks are "surveillance, assertion of sovereignty and rescue operations". All countries recognise the task of supporting other civilian authorities e.g. in disaster relief. A third common task definition is peacekeeping or participation in international crisis management, which takes place outside the national territory.

The Military Balance (2014) contains the following notes of the tasks of each country's defence forces: Denmark's armed forces are geared towards participation in international missions; the primary role of Finland's armed forces is to act as a guarantor of national sovereignty by providing territorial defence, and its combination of a conscript/reserve-based structure with a modern equipment inventory is shaped to support this aim. Territorial defence is the primary role of the armed forces and Sweden's power-projection capabilities are limited. Norway maintains small but capable armed forces focused largely on territorial defence, particularly in the High North. Saxi $(2011$, p. 70) shares this view and writes on the Nordic countries that for Denmark the challenges and threats are de-territorialised and could come from anywhere, but typically far away. Sweden shares this threat perception, with a caveat for Russian power in the Baltic Sea. Norway is concerned about its High North region and Russia, but also feels the need to employ resources to deal with global challenges and threats. Finland, like Norway, is simultaneously concerned with its shared border with Russia, as well as the challenges of globalisation, but Finnish defence efforts are markedly concentrated on the former.

\section{Nordic Military Budgets}

What are the means for achieving these tasks? According to information from the Stockholm International Peace Research Institute (SIPRI), military spending in 2014 in relation to GDP was at the same level in each country, with slightly lower spending in Sweden. The trend in Nordic countries since the end of the cold war has been similar to the general downward trend in Europe with the exception of Finland, whose outlays have reduced less (Figure 1). While these trends reflect the perception of the security situation after the end of the cold war, they also give rise to calls for savings and more effectiveness e.g. through co-operation. 


\section{Military Budget Breakdown}

There is no single comprehensive source for a military spending breakdown of the Nordic countries. Each country publishes national data on defence spending, but even when comparable items can be found, it is often not clear exactly to what extent the definitions and calculation methods are identical. The EDA publishes statistics, but unfortunately not on Norway and Denmark. The National United Nations Military Expenditure (MILEX) database includes in principle comprehensive cost data in detail. Unfortunately, not all countries submit reports every year and even if they do, they could file a simplified version with only summary figures. Reports for Sweden

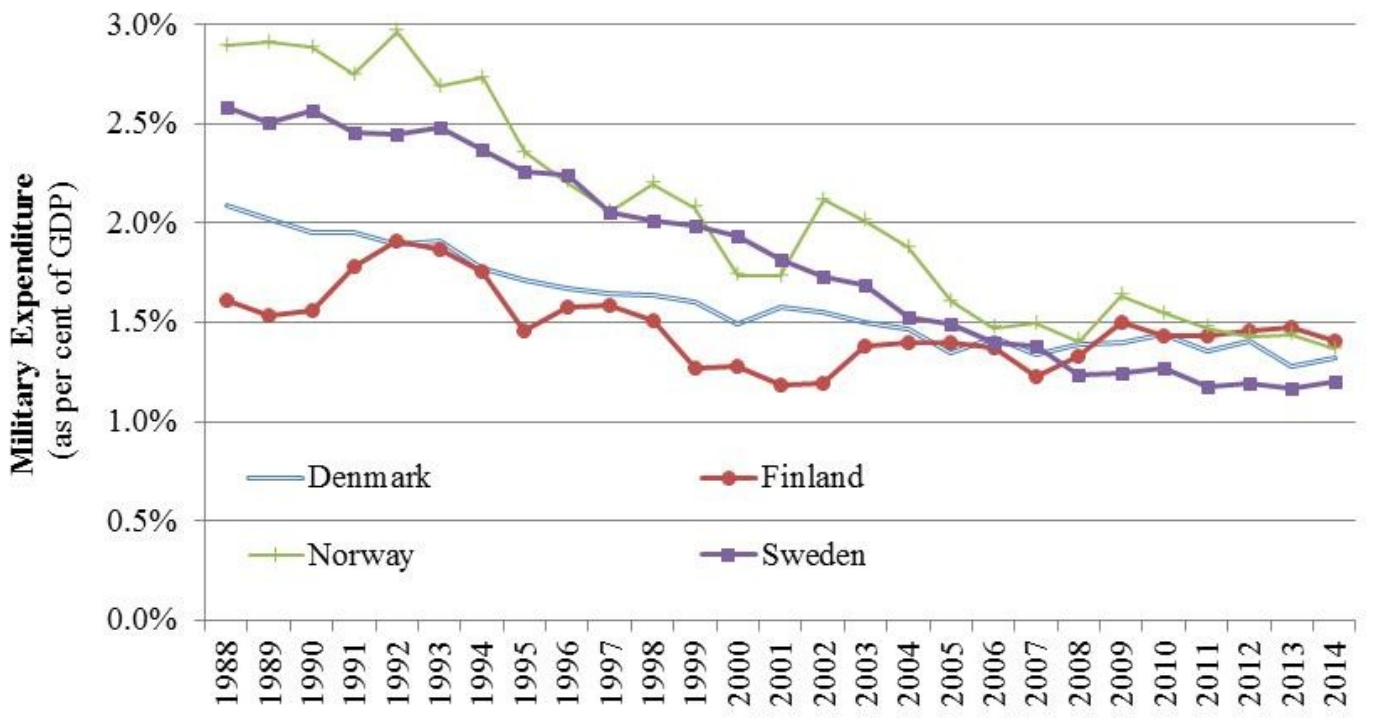

Figure 1. Development of military expenditure in the Nordic countries (SIPRI, 2015).

are missing for the years 2011 and 2012. Denmark has supplied a standardised report only in 2012 and even that does not contain a breakdown of purchasing. Norway likewise has not submitted any reports in 2011 and 2012 and those that Norway has submitted do not contain a further breakdown of purchasing. Only Finland has submitted standardised reports each year. For the year 2013 all Nordic countries have filed reports, although Norway and Denmark, a simplified one. Figure 2 shows the breakdown of defence expenditure in 2013 according to MILEX reports. 


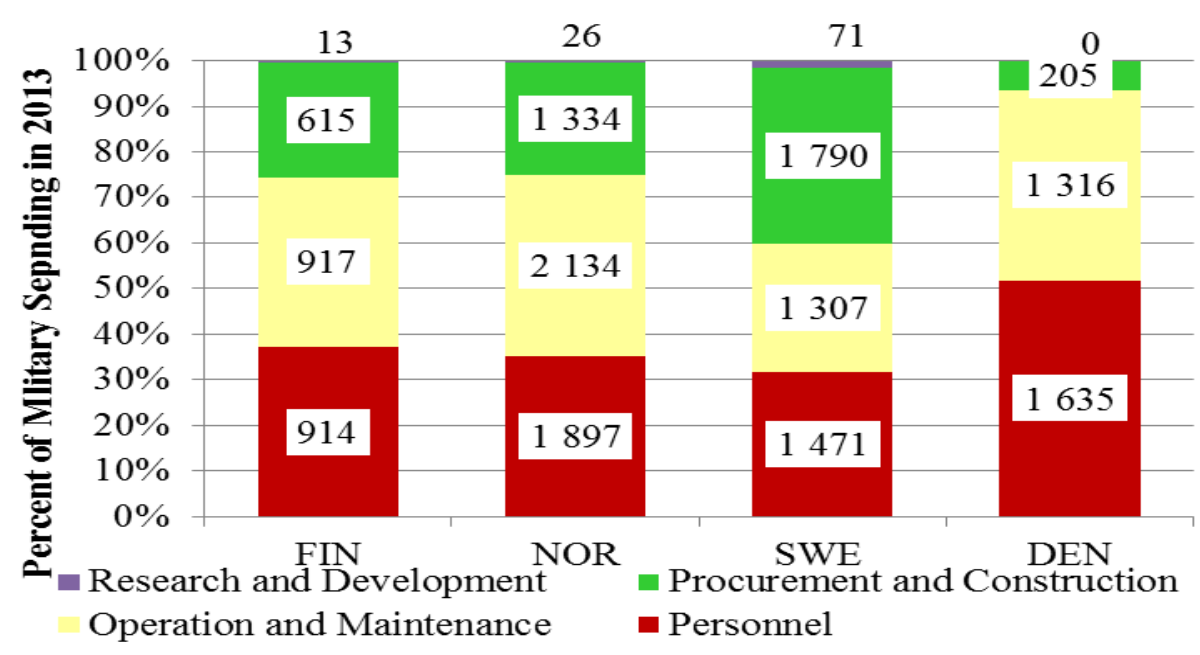

Figure 2. Breakdown of military spending in Nordic countries in 2013. Figures in euros and exchange rates applied: $1 €=7.8067 \mathrm{NOK}, 8.656 \mathrm{SKR}, 7.4548 \mathrm{DK}$ (UNODA, 2015a).

In absolute terms, Sweden spends more than any other Nordic country in defence and Finland the least, being $46 \%$ of that of Sweden. At the European level, the breakdown figures by the European Defence Agency (2015) in 2013 were: a half in personnel (49.3\%), a quarter $(25.1 \%)$ in operation and maintenance, a fifth $(20.1)$ in investment, of which $16.1 \%$ is equipment procurement and $4.0 \% \mathrm{R} \& \mathrm{D}$, the remainder being other expenses, which includes infrastructure and construction. When making a cross-check for Finland for the year 2013, the EDA figures give 37 M€ for R\&D, while the UN Office for Disarmament Affairs (UNODA) gives 13 $\mathrm{M} €$, which is a large discrepancy. According to the EDA, even the personnel expense in Finland was $32 \mathrm{M} €$ lower than UNODA. In addition to comparability issues, the figures are from one year only and should be treated accordingly. However, the following observations can be made by comparing the numbers in Figure 2 and the European averages for the year 2013:

- Denmark is different from the three other Nordic countries with respect to spending with more spending on personnel and less on procurement.

- Equipment procurement is a larger portion of the expenditure in Norway, Finland and especially Sweden than the European average, although some of this may be due to differences in reporting of construction expenses between the UNODA and EDA data. 
- Procurement and operation and maintenance is about two thirds in Sweden, Finland and Norway while Denmark is close to the European average where a half is spent on personnel.

- R\&D in Nordic countries is almost negligible in comparison to the European average of $4.0 \%$ as R\&D is in Norway $0.5 \%$, in Finland either $0.5 \%$ according to UNODA or $1.5 \%$ according to the EDA and in Sweden it is $1.5 \%$ of military expenses.

\section{$R \& D$ and defence industry}

Historically, Sweden has had a broad and advanced defence industrial base, high defence technological ambition and competitive successes (Hagelin, 2006). Recently this domestic acquisition policy has been abandoned and the 2008 defence bill lays down principles that preference should be given to the purchase of fully developed systems that are already available on the market, even if the Swedish industry would be able to develop and produce an alternative (Bromley \& Wezeman, 2013). This is quite similar to the Finnish procurement policy, which states that foreign procurement should focus on ready-made and tested materiel (FMoD, 2015), i.e. military off-the-shelf (MOTS) equipment. Relatively small Nordic countries do not have the resources to maintain such a strong national defence industrial base as the large European countries, except perhaps for Sweden.

Table 1. Nordic arms trade between 2009 and 2014. Values are SIPRI's Transport value indicator (TIV) values, which are expressed in 1990 USD and are indicative only (SIPRI, 2015)

\begin{tabular}{|l|c|c|c|c|r|}
\hline & \multicolumn{4}{|c|}{ Export from } & \multicolumn{2}{|c|}{$\begin{array}{l}\text { Percent of total } \\
\text { Import to }\end{array}$} & FIN & NOR & SWE & DEN & imports \\
\hline FIN & - & 70 & 81 & 0 & $22 \%$ \\
\hline NOR & 0 & - & 15 & 0 & $7 \%$ \\
\hline SWE & 33 & 8 & - & 0 & $16 \%$ \\
\hline DEN & 0 & 0 & 75 & - & \\
\hline
\end{tabular}

The limited defence industrial base translates, in addition to small $R \& D$ expenditure in comparison with the European average, also to a small Nordic trade in military equipment. This can be seen in the last column of Table 1, which contains a matrix of the Nordic arms trade in 2009-2014, according to Sipri's assessment. The last column shows the percentage of Nordic imports as of each country's imports. Hagelin (2006) reached similar conclusions on Nordic co- 
operation, as he wrote that there is not really an intra-Nordic arms market. In fact, Nordic co-operation seldom involves all four countries and quite often only two of them. As problems, Hagelin mentions the imbalances that result from both the dominant role of Sweden's defence industry and the limited defence industrial base in Denmark. Given a decade of deepening Nordic co-operation since Hagelin's paper, little seems to have changed in this respect.

A small $R \& D$ and limited defence industrial base means a need for importing defence equipment. The NH90 helicopter is a good example that highlights what this means to possibilities for co-operation. The NH90 was developed in collaboration by a consortium initially consisting of large countries Germany, France, Italy and the Netherlands that also had procured the NH90 for national defence forces while the Nordic procurement co-operation under the Nordic standard helicopter program (NSHP) led to Finland, Sweden and Norway signing procurement contracts for the NH90 in the autumn of 2001 (Lehtonen \& Anteroinen, 2013). Nordic countries, especially other than Sweden, tend to purchase existing equipment from the market instead of investing in $R \& D$ and developing military equipment either alone or in European collaborative equipment programs.

\section{Procurement by Equipment Category}

Table 2. Breakdown of military purchasing (UNODA, 2015a)

\begin{tabular}{|l|r|r|r|r|r|}
\hline Procurement & SWE & FIN & \multicolumn{1}{l|}{ FIN } & \multicolumn{1}{l|}{ FIN } \\
& 2013 & 2013 & 2013 & 2012 \\
\hline Aircraft and engines & $43 \%$ & $39 \%$ & $39 \%$ & $28 \%$ \\
\hline Missiles & $1 \%$ & $8 \%$ & $8 \%$ & $4 \%$ \\
\hline Ships and boats & $13 \%$ & $4 \%$ & $4 \%$ & $9 \%$ \\
\hline Armoured vehicles & $3 \%$ & $0 \%$ & $0 \%$ & $0 \%$ \\
\hline Artillery & $2 \%$ & $0 \%$ & $0 \%$ & $1 \%$ \\
\hline Other ordnance and ground force weapons & $2 \%$ & $16 \%$ & $16 \%$ & $23 \%$ \\
\hline Ammunition & $0 \%$ & $0 \%$ & $0 \%$ & $2 \%$ \\
\hline Electronics and communications & $24 \%$ & $20 \%$ & $20 \%$ & $7 \%$ \\
\hline Non-armoured vehicles & $5 \%$ & $0 \%$ & $0 \%$ & $0 \%$ \\
\hline Other & $8 \%$ & $12 \%$ & $12 \%$ & $26 \%$ \\
\hline
\end{tabular}

Table 2 shows the breakdown of military purchasing item in existing MILEX standardised reports, which for Sweden is only for 2013. Comparing the 2013 
figures between Finland and Sweden, one can see that there are substantial differences but also that aircraft and engines is the largest category in both countries. As can be seen from comparing the 2012 and 2013 figures for Finland, the spending breakdown is highly variable due to the timing of individual purchases.

\section{Operation and Maintenance}

Operation and maintenance (Figure 2) is a large and diverse class of spending. Unfortunately, the UN reporting guidelines do not offer much help. In a standardised report, the operation and maintenance is divided into four subclasses: 2.1 Materials for current use; 2.2 Maintenance and repair; 2.3 Purchased services; and 2.4 Other. The explanation for 2.1 includes materials such as food, clothing and petroleum but also "tools for repair and maintenance of equipment and facilities". Exactly the same wording is also in sub-item 2.2, whose other content is contract services for repair and maintenance, which in turn is similar to 2.3. The guidelines for 2.3 state that it should include various kinds of purchased services such as travel expenses, postal charges, printing expenses and other. Given such guidelines, the comparability of the reports at the sub-item level would be questionable even if Nordic countries other than Finland would file standardised reports consistently.

It is not clear why only Finland reports data to the UN comprehensively and consistently. However, one could contrast the breakdowns requested by UNODA with the annual reports by Norway and Sweden. Those have different spending breakdown structures. Norway (Forsvaret, 2014) reports spending by function, such as operations in home guard, army, navy, coast guard etc. Likewise, cost breakdown as reported in Sweden's defence force annual report is by function such as service branch (Försvarsmaketen, 2014), not cost type. Without a detailed knowledge of the cost accounting systems and organisations in use in different countries, it is not possible to say if Norway or Denmark even could report spending according to the UNODA (2015b) guidelines.

\section{Savings and cost-effectiveness}

The word savings implies a comparison to another alternative that is more expensive. In a concrete accounting context, for example, the savings of customer service staff reduction could be compared to keeping service staff at the current level. The reduction in staffing could affect service availability, which in turn may 
affect sales. Although such influences can be tricky to calculate in practice, in principle they should be included in the evaluation. In public finances, the savings could simply be a comparison of the same item in consecutive budget years or a comparison at the real decision situation, i.e. comparing future expenditures with and without some action. Under the budget expenditure interpretation, any savings should actually mean less spending.

Unlike for private enterprise, in the public sector the outcome may often not be directly and meaningfully measured in monetary terms. The purchase price of, e.g. a fighter aircraft is quite straightforward but the military capability provided by it cannot be expressed monetarily, unlike the calculation of the net present value of an investment decision in the private sector. As already mentioned, Søreide (2014) saw improved cost-efficiency as an overarching goal for NORDEFCO and costeffectiveness could be seen as value-for-money thinking. NORDEFCO cooperation may open up opportunities where doing it alone is not currently being done. As an example, let's take the joint anti-submarine warfare exercise mentioned in the defence co-operation report (SMoD, 2015). Finland does not own submarines while Sweden does. Without co-operation, Finland may either do antisubmarine exercises without a submarine or - highly unlikely - acquire one for the purpose. In this case, any savings of co-operation under the budget expenditure interpretation may be unclear or even negative. Savings depend on the choice of alternatives, and for the purpose of this article, the comparison is made to the baseline of the present arrangements.

\section{Savings through Co-operation and Merging of Activities in Theory}

Economies of scale refers to the situation where larger volumes in production, distribution or other activities achieve lower unit costs. This effect is well known and ubiquitous in economics and has various causes, which means its amount therefore is context dependent. Porter (1979) views economies of scale as first among the major sources of entry barriers to industry. In process industry investments, an economies of scale factor to the power of two thirds is sometimes mentioned as a rule-of-thumb. Pugh (2012) mentions economies of scale arising from being able to share the fixed costs of a product design to a larger amount of production units in weapons acquisition. Arena et al. (2006) estimate the economies of scale at an average rate of $10 \%$ for a doubling of production volume for US Navy ships. 
In a merger, economies of scope arise when a firm achieves cost savings as it increases the variety of the activities it performs (Capron, 1999). Capon writes about horizontal mergers between firms and in such a merger, these economies of scope come from the indivisibility of assets and underutilisation of capacity as a merger provides an opportunity to rationalise production. Kvalvik and BergKnutsen $(2009$, p. 4) define economies of scope as cost reductions originating from the use of a joint resource in the production of different, but related, products or services.

Stevenson (2011) explains the learning curve as a phenomenon where human performance typically shows improvement when done repeatedly, and for more complex tasks the improvement occurs over a larger number of repetitions. A more general phenomenon is called an experience curve, which means that the time to manufacture of a single unit decreases as a function of the cumulative production volume. The form of the experience curve is exponential, i.e. each doubling in cumulative volume will decrease production time per unit by a constant percentage. This is caused by a combination of elements, including economies of scale, the learning curve of labour and capital-labour substitution (Porter, 1979). Empirical evidence shows that typical values of savings due to experience are between $10 \%$ and 20\% (Stevenson 2011). According to Hartley (2008), modern combat aircraft such as the Typhoon are subject to a $10 \%$ to $15 \%$ savings in unit production costs for every doubling of the cumulative production volume.

In their theoretical account on levers to improve efficiency in defence, Kvalvik and Berg-Knutsen (2009) present the three factors above and add a fourth one, the organisation-specific circumstances that are those differences of effectiveness between organisations that are not explained by the three factors above. In addition, they present transaction costs as a factor mitigating the efficiency gains from scale and scope. Although not strictly involving a business transaction, they take up the concept of internal transactions as a source of negative economies of scale. Moreover, they see these theoretical factors as being applicable both to internal effectiveness improvement as well as a source of efficiency gains in co-operation between defence forces.

The efficiency gains through scale, scope and learning accrue at the producer, and it is a matter of negotiation or markets to what extent they are divided between the buyer and seller. Nordic countries, with relatively small domestic defence industrial bases, seldom design and produce their own equipment but procure outside the Nordic area, often so-called MOTS equipment. Therefore these three sources of 
efficiency gains, which refer to production or more generally operations, are not necessarily passed on to the buyer. Secondly, the efficiency gains in production can often be small or negligible, as is the case when the selling country or consortium is a large one and Nordic volumes, even if combined, in comparison, are very small. For example, if the USA produces 2000 units for itself, combining 50 units from Norway, Denmark and Finland, respectively, would triple the Nordic volume but would increase the total production volume by only $7.5 \%$. Kvalvik and BergKnutsen (2009) notice the same facts between economies of scale and the relative sizes of Norway (1), Nordic co-operation (x4) and USA (x100) while drawing the conclusion that co-operation with the USA has that much more savings potential.

\section{Savings through Co-operation and Merging in the Defence Context}

Smart defence, a recent NATO initiative, intends to achieve improved military capabilities and savings by national capabilities alignment, which is the specialisation of each nation to do what they do best and capability co-operation to achieve economies of scale (NATO, 2012). Corresponding efforts are called pooling and sharing by the EDA. More specifically, pooling refers to having capabilities on a collective basis while sharing means that some countries relinquish some capabilities with the assumption or guarantee that other countries will make them available when necessary (EDA, 2011).

Pooling and sharing is an old concept; it appears in the 2003 European security strategy, and both the EU and NATO have agencies dedicated to identifying joint projects (Valášek, 2011). Hartley (1983) describes how wasteful duplication was tackled during the late 1970s with NATO objectives of standardisation and interoperability through rationalisation, collaboration, co-operation and co-production efforts. Heuninckx (2008) recounts that European armaments co-operation began in the 1950s and that there have been an estimated 59 collaborative defence procurement programmes to date. From 2006 to 2012, the share of collaborative defence equipment procurement has been around 20\%-25\% (EDA, 2015).

The Ghent initiative (2010) text advertises the benefits of pooling and sharing in the following way: "There are great profits to be made by finding ways of sharing expenses and burdens. . . . By bundling national demand, potential savings could be realised through economies of scale." Another argument in favour of collaboration is that it is the only way to build complex platforms that could no longer be produced by any single country's industrial base (Giegerich \& Nicoll, 2012), 
although it is mentioned in the Ghent initiative, too. As Nordic countries, apart from Sweden, don't have much of a defence industrial base and therefore each acts as a purchaser, not a product developer and producer, the latter argument needs to be rephrased from building to purchasing or maintaining. However, joint ownership or maintenance are much more sensitive issues than co-operative development but independent ownership of equipment. According to Saxi (2011), the size of armed forces for large states, such as the UK, France and Germany, allows them to equip and train national forces, but smaller European countries are approaching the point at which they find it increasingly difficult to retain the full range of military capabilities unless they increase international co-operation. But he doesn't acknowledge the fact that co-operation through pooling and even less with sharing does not actually enable retaining the full range of military capabilities, at least not entirely under national control.

Against the shortlist of co-operation and collaboration benefits there are a number of problems that successful co-operation efforts have to tackle. One drawback is the loss of sovereignty. Co-operation and specialisation benefits will come at the price of reduced national autonomy (Gierich \& Nicoll, 2012). Järvenpää (2013) sees that difficulties in pooling and sharing increase the closer one gets to the core of defence plans and to essential key capabilities that are needed to defend a nation if attacked. Likewise, Saxi (2011, p. 61) wonders if political-level support will endure when co-operation reaches concrete and specific points, affecting jobs, contracts and military bases. A third problem is the harmonisation of military requirements, an issue taken up also in the Ghent initiative. According to Gierich and Nicoll (2012), there is a tendency, in spite of the collaborative nature of projects, to produce in fact national versions of the equipment, considerably reducing the economies of scale that could be achieved. In the Nordic NH90 cooperation, Finland purchased a tactical transport (TTH) variant, Sweden the same TTH variant but 13 of 18 as a high cabin version and Norway chose the NATO frigate (NFH) version (Lehtonen \& Anteroinen, 2013). The inherent difficulties in ensuring that all participants in any collaboration have their interests aligned is widely held to be the root cause of many problems (Gray, 2009), a view that nicely sums up all the three previous problems.

In addition to very theoretical calculations by Kvalvik and Berg-Knutsen (2009) that are based on a $20 \%$ savings for a doubling of volume by co-operation, the McKinsey report on defence productivity (Staples, 2013) provides some calculations at least on the potential benefits of collaboration at the European level. Europe has six times the number of weapon systems that the US has and 
consolidating procurement would make batch sizes 2.5 times larger, something that McKinsey calculates could yield through pooling the procurement a long-term savings up to $30 \%$, while sharing the depot-level maintenance for the top 12 aircraft platforms would save 500-600 M€ annually (Staples, 2013). The report continues to assert that this savings potential exists only in the long term and does not help in current budget cuts. Valášek (2011, p. 34), on the other hand, reminds that it often costs more in the short term because bases may need to be closed, units moved or those made redundant paid off.

Finally, the costs of co-operation may actually outweigh the benefits. Perhaps some of the strongest arguments levelled against NORDEFCO concern the time spent travelling to and from meetings, partaking in working groups and the hours spent preparing for these activities (Saxi, 2011). Hagelin (2006) refers to a conclusion in 2004 by members of NORDEFCO's precursor NORDAC that it has been a success if success is measured broadly and is based on relatively few large - and many small - completed undertakings, but the conclusion may be different if these successes are measured against the time, cost and other resources lost on unsuccessful undertakings. According to Saxi (2011), when asked why they chose NORDEFCO instead of a European or a transatlantic setting, both of which are larger with even better economies of scale than NORDEFCO, Swedish, Finnish, and, to a lesser extent, Norwegian defence officials respond that NATO, and especially the EU, are too slow, large, heterogeneous and cumbersome.

\section{Nordic Acquisition Plans and Co-operation Opportunities}

In order to realise the savings potential of the economies of scale and learning curves that were explained in the theoretical section through co-operation, such cases for co-operation have to be identified. NORDEFCO has a process for this and its action plan (2013) contains activities that "continuously compare national capability development plans in order to present identified short, medium and long term co-development areas" and "suggest armament procurement priority changes in respective nations procurement plans in order to facilitate common acquisitions." However, as the results are not public, in the following an independent assessment of the savings potential for acquisition through co-operation is presented.

\section{Finnish Acquisition Plans}

Finland has published very little about possible future procurement plans for military equipment. According to the speech made by Commander of the Defence 
Forces Lindbergh (2015), the major future procurement plans include replacing the F/A-18 combat aircraft sometime around 2025-2030 and a fleet2020 project that will maintain the navy's capabilities as Rauma-class fast attack craft and Hämeenmaa-class minelayers reach the end of their life-cycles.

\section{Danish Acquisition Plans}

The Danish Defence Agreement (2012) lists as its biggest items the replacement of F-16 combat aircraft, one offshore patrol vessel of the Knud Rasmussen-class and maritime helicopters. There are also other items or classes of items including armored personnel carriers (APC), artillery and radar systems as well as three separate lines listing communications equipment. There are no figures attached to individual items. However, the Defence Agreement states that annual procurement budget will stay at 1,200 MDK (160 MEUR) and the new combat aircraft purchase is to be financed inside the planned defence budget. Furthermore, it says that "Danish defence has great potential for ensuring better and cheaper procurement through expanded use of framework agreements, concentration of the supplier base, centralization of purchases into significantly fewer functions, as well as the establishment of a strengthened and more coordinated organization for handling the defence procurement." It is interesting to note that it fails to take up any potential for better and cheaper procurement through Nordic co-operation.

\section{Norwegian Acquisition Plans}

Norway has published a future acquisition plan (FAF) for 2014-2022 (Forsvarsdepartementet, 2014). The document does not include those projects that are already decided although overall procurement figures apparently also include those. Total spending in the plan amounts to $108 \mathrm{Mrd} \mathrm{NOK}$, which is about $€ 13.5$ Mrd (7.8 NOK $=€ 1)$. About $44 \%$ of the money will be spent on F-35 acquisition. Other big items are the replacement of three coast guard vessels of the Nordkappclass, a submarine after the 2020 project, as well as ongoing NH90 helicopter deliveries and land vehicles for the army. The acquisition plan lists a total of 68 possible or planned projects and their planned minimum and maximum costs. Projects larger than $500 \mathrm{MNOK}$ (c. $60 \mathrm{M} €$ ) are called major projects and decided in Parliament. Out of the 68 projects, four have an average range over 500 MNOK. These are: Leopard upgrade, Nordkapp-class replacement, airspace surveillance sensors and tactical command system for land forces. Of the 68 projects, about 13 include upgrades of existing equipment. 
The sum of planned costs (range average) of the 68 projects in the list is $22.9 \mathrm{Mrd}$ NOK or about $330 \mathrm{M} €$ a year, which accounts for less than half of the spending plan of 108 Mrd NOK even after subtracting the F-35 project. How much of the missing value consists of projects that are already decided and therefore do not show in the listing of planned projects, like the F-35 or NH90, how much is spending allocated to projects that aren't yet even planned and how much is projects that don't have planned value, like submarines after 2020, is unclear. However, it is clear that major acquisition projects take years from the decision to realisation as budget expenditure and also that the actual amount and timing of expenditures may deviate from the plan.

It is especially mentioned that purchases through the NSPA (NATO Support Agency) or NATO Communications and Information (NCI) Agency should always be considered while there is no comparable recommendation for Nordic cooperation in the FAF document.

\section{Swedish Acquisition Plans}

In addition, Sweden publishes its future acquisition plan (Försvarsmakten, 2013). The major items of land equipment are the new artillery system, Archer, upgrades of the Leopard tank and CV90 vehicle and other land vehicles. Also, ground-based air defences and handguns as well as night vision equipment and engineering equipment will be purchased. In the navy, main projects are a Visby-class corvette, a next-generation submarine, a light torpedo and a surveillance vessel while a new surface combatant is planned after 2020. The Air Force continues development of the JAS 39 and has ordered the JAS type E. The helicopters NH90, A109 and UH60 will be made operational and an upgrade of the transport aircraft C-130 will be started. Communications systems will be made IP-based and, among other things, a new tactical radio system will be acquired. In the detailed list there are 111 separate items of which all but six have an average cost range under 500 MSEK or c. $60 \mathrm{M} €$ (8.68 SEK = 1 EUR, 2013). Even small items are listed, like project $A A .3413603$ swimming vest with a planned cost in the range of 0.17-0.29 M€. The sum of individual projects (range average) is $16.3 \mathrm{Mrd}$ SEK, which is about $1.9 \mathrm{Mrd} €$ or $235 \mathrm{M} €$ annually - a figure that does not come even close to the 2013 purchasing volume in Figure 1. This is perhaps due to the list including only planned projects.

Concerning co-operation there is a statement about "a general desire for increased international collaboration in acquisition". In addition, there are two specific references to a desire for Nordic co-operation, one on the acquisition of 25,000 
personal weapon systems (handguns) for a planned cost of 40-50 M€ and another for collaboration on NH90 "when appropriate".

\section{Comparison of the Acquisition Plans}

When comparing the lists of future acquisition plans, it becomes evident that there aren't very many similarities in the lists. Finland and Sweden both plan for somewhat similar surface combatants around 2020, but Norway's coast guard vessel is already a different project and Denmark plans for a specific Knud Rasmussen-class offshore patrol vessel. Sweden and Norway both plan for future submarines, but with the background of the co-operative Viking-project, cooperation looks challenging. Hagelin (2006) describes the co-operative Viking submarine project as "an even bigger failure than the NH90-project, where Finland never was a member, Norway changed from a member to observer in 2003 and Denmark decided not to purchase submarines in 2004". Leopard MBT tanks will be upgraded both in Norway and Sweden, and as Finland also is a user, it might upgrade its fleet, too. Denmark lists both artillery and APCs as future purchases in its defence agreement while Norway's FAF includes as a major item an infantry fighting vehicle (CV90) and artillery. In Sweden, major purchases for the Army include the Archer artillery system and an upgrade of the CV90. What has happened is that Norway has pulled out of the Archer project and is searching for another option (Bruun-Hanssen, 2015) and according to IHS Jane's (2015), Denmark announced in April that it has selected the MOVAG Piranha 5 APC and is halting its self-propelled artillery plans. Both Norway and Sweden are planning to purchase vehicle-launched bridges but Sweden's plan already calls for using the Leopard 2A4 chassis. Handguns are marked in the Swedish list as "co-operation desired" and Norway has its future warrior project. Undoubtedly there could be further possibilities e.g. in radar and communications equipment as well as some minor projects, but as the future acquisition plans do not describe them in detail, it is not easy to spot clear opportunities in those areas.

The process of comparing the results of national acquisition plans appears unable to produce savings that would make a difference at the defence budget level. To what extent this may be caused by differences in defence forces' tasks and structures cannot be concluded by just looking into these end results of defence planning, but it could be a contributing factor. Another reason is timing, which often cannot not be synchronised due to differences in the end of life cycle of existing equipment. Timing may appear to be an issue that could be synchronised if 
the willingness exists. On the other hand, if savings in co-operation were $20 \%$ and equipment life cycle is 30 years, then pulling forward the acquisition by just six years would negate any possible savings for that party. Moreover, if the life cycle is 30 years, the probability of any two countries reaching the end of the life cycle inside the six-year time-window is, well, $20 \%$.

The comparison of future acquisition plans for each Nordic defence force does identify some opportunities for co-operation. Even if one would set aside the major expenditure item, the fighter aircraft, the proportion of such potential projects is a very small slice of the entire procurement plan. While this does not negate cooperation benefits for those specific projects, it limits the potential to a small part of overall procurement. Table 3 below shows a rough assessment of the potential in comparison to total military expenses. The procurement and construction in 2013 was on the average $25 \%$ of the defence budget in the Nordic countries. If cooperative procurement could reach $20 \%$ of defence procurement, which is about the share of European collaborative defence procurement programs (EDA, 2015), the co-operation would affect $5 \%$ of the Nordic military expenses. The actual savings potential will depend on many of the issues that have been discussed. If we assume a $10 \%-15 \%$ experience curve, that Nordic procurement is the sole purchaser of the equipment, that all gains are captured by the purchaser, there is no co-operation costs, and a participation of two or four countries, we get savings of $10 \%-30 \%$ in Table 3. The last column shows that this potential is between $0.5 \%-1.5 \%$ of the total Nordic military budget assuming 2013 actual figures. When comparing the savings potential in Table 3 with the actual achievement of $100 \mathrm{M} €$ savings over a 15-year period, i.e. 6.7 M€ per year, even the low potential has not yet been fully realised.

Table 3. Assessment of savings potential in NORDEFCO co-operative armaments purchasing

\begin{tabular}{|l|r|r|r|r|r|r|}
\hline Savings potential calculation & FIN & NOR & SWE & DEN & Total & $\begin{array}{l}\text { Percen } \\
\mathrm{t}\end{array}$ \\
\hline Military Expenses 2013 & 2,45 & 5,39 & 4,63 & 3,18 & 15,67 & $100 \%$ \\
& 9 & 0 & 9 & 2 & 1 & \\
\hline $\begin{array}{l}\text { Of which Procurement and } \\
\text { Construction }\end{array}$ & 615 & $\begin{array}{r}1,33 \\
4\end{array}$ & $\begin{array}{r}1,79 \\
0\end{array}$ & 205 & 3,944 & $25 \%$ \\
\hline Co-operation share 20\% & 123 & 267 & 358 & 41 & 789 & $5.0 \%$ \\
\hline Savings 10\% & 12 & 27 & 36 & 4 & 79 & $0.5 \%$ \\
\hline Savings 20\% & 25 & 53 & 72 & 8 & 158 & $1.0 \%$ \\
\hline Savings 30\% & 37 & 80 & 107 & 12 & 237 & $1.5 \%$ \\
\hline
\end{tabular}


In a 2012 Skagen meeting, the Nordic defence ministers also discussed potential co-operation areas where in the short term, "airspace surveillance, procurement of small arms ammunition, tugboats, armored vehicles rubber tracks, batteries and unit group rations provide good opportunities for positive results" (DDF, 2012). As airspace surveillance opportunity does not involve procurement, the rest of the list pretty much speaks to the magnitude of opportunity in procurement.

\section{Communality in Military Equipment}

The operations and maintenance costs were a major defence spending category in Figure 2. It is also often cited that operations would account for $70 \%$ of life-cycle costs while acquisition price would be only $30 \%$, although Jones et al. (2014) find an average ratio of 55:45 with many weapons systems deviating significantly from the average. While maintenance costs may not be the majority of operating costs, maintenance could also offer savings through co-operation. Maintenance costs come from labour, spares, tools and equipment and facilities. Economies of scale help to drive down costs in work (due to e.g. learning) and in equipment and facilities, for example if utilisation can be increased. Spares cost may be lowered due to larger volumes. The economies of maintenance co-operation or centralisation are not easy to assess, because there are many ways to realise cooperation (e.g. central facility or moving labour team) and different types of maintenance operations for different platform subsystems. The existing example of maintenance co-operation is the framework agreement between Denmark and Norway C-130 transport aircraft that "provides a saving of up to 7\% in services due to larger service volumes" (NORDEFCO, 2015b).

To a significant extent, potential savings from merging and centralising maintenance operations presuppose the same equipment. As spares, knowledge and learning and to some extent even tools are specific to the equipment type and its subsystems, it follows that co-operation saves more clearly when the equipment is of the same type. In the following table, a comparison of the military equipment types and their similarity is studied through information in the Military Balance (2014). 
Table 4. Military vehicle types in Nordic countries. Numbers in parentheses (Military Balance 2014)

\begin{tabular}{|l|l|l|l|l|l|}
\hline & \multicolumn{1}{|c|}{ FIN } & \multicolumn{1}{c|}{ NOR } & \multicolumn{1}{c|}{ SWE } & \multicolumn{1}{c|}{ DEN } & Common \\
\hline MBT & LEO 2A4 (100) & $\begin{array}{l}\text { LEO 2A4 } \\
(52)\end{array}$ & $\begin{array}{l}\text { LEO 2A4 (12); } \\
\text { 2A5 (120) }\end{array}$ & $\begin{array}{l}\text { LEO 2A4/5 } \\
(55)\end{array}$ & $339 / 339$ \\
\hline AIFV & $\begin{array}{l}\text { CV90 (102); } \\
\text { BMP-2 (110) }\end{array}$ & $\begin{array}{l}\text { CV9030N } \\
(104)\end{array}$ & CV9040 (354) & CV9030 (45) & $605 / 715$ \\
\hline $\begin{array}{l}\text { APC } \\
\text { track) }\end{array}$ & $\begin{array}{l}\text { MT-Lbu (40); } \\
\text { MT-LBV (102) }\end{array}$ & M113 (315) & $\begin{array}{l}\text { Pbv 302 (194); } \\
\text { BvS10 MkII } \\
(48)\end{array}$ & M113 (343) & $658 / 1046$ \\
\hline $\begin{array}{l}\text { APC } \\
\text { (wheel) })\end{array}$ & $\begin{array}{l}\text { XA-180 (260); } \\
202 / 3(149) ; 360 \\
(62)\end{array}$ & XA-186 (75) & $\begin{array}{l}\text { XA-180 (23); } \\
202 / 3(137) ; \\
360(1)\end{array}$ & $\begin{array}{l}\text { Piranha III } \\
(111)\end{array}$ & $707 / 818$ \\
\hline Recon & BMP-1TJ (34) & Fuchs & & $\begin{array}{l}\text { Eagle I (22); } \\
\text { IV (91) }\end{array}$ & $0 / 147$ \\
\hline PPV & & Dingo II (20) & RG-32M (260) & Cougar (40) & $0 / 320$ \\
\hline
\end{tabular}

Table 4 shows that there are a lot of similarities in the land vehicles of Nordic countries. The last column (common) shows the volume of the same equipment and the sum of all equipment in that row. All these countries have some version of the Leopard as the main battle tank as well as some version of the Swedish CV90 combat vehicle, but Finland also has the Russian BMP-2. In APCs, all Nordic countries except Denmark have some version of the wheeled Finnish XA vehicle, while in tracked APCs, NATO countries Norway and Denmark have the American M113.

Table 5. Fixed-wing aircraft types and numbers in Nordic countries (Military Balance 2014)

\begin{tabular}{|l|l|l|l|l|l|}
\hline & \multicolumn{1}{|c|}{ FIN } & \multicolumn{1}{c|}{ NOR } & \multicolumn{1}{c|}{ SWE } & \multicolumn{1}{c|}{ DEN } & Common \\
\hline Fighter & $\begin{array}{l}\text { F/A-18 C/D } \\
(65)\end{array}$ & $\begin{array}{l}\text { F-16 A/ } \\
(57)\end{array}$ & JAS 39 (134) & $\begin{array}{l}\text { F-16 } \\
(45)\end{array}$ & $102 / 301$ \\
\hline Training (jet) & $\begin{array}{l}\text { Mk50/51A (29); } \\
\text { Mk66 (16) }\end{array}$ & - & Sk-60W (80) & - & $0 / 125$ \\
\hline $\begin{array}{l}\text { Training } \\
\text { prop) }\end{array}$ & L-70 (28) & $\begin{array}{l}\text { MFI-15 } \\
(15)\end{array}$ & - & $\begin{array}{l}\text { MFI- } \\
17(27)\end{array}$ & $42 / 70$ \\
\hline $\begin{array}{l}\text { Transport } \\
\text { (med) }\end{array}$ & - & $\begin{array}{l}\text { C-130J } \\
(4)\end{array}$ & C-130E/H (7) & $\begin{array}{l}\text { C-130J } \\
(4)\end{array}$ & $15 / 15$ \\
\hline Transp. (light) & C-295M (2) & - & Saab 340 (2) & - & $0 / 4$ \\
\hline EW/ELINT & C-295M (1) & $\begin{array}{l}\text { Falcon } \\
\text { 20C (3) }\end{array}$ & $\begin{array}{l}\text { Gulfstream } \\
\text { IV (2) }\end{array}$ & - & $0 / 9$ \\
\hline
\end{tabular}


Table 5 shows that there are fewer similarities in the fixed-wing aircraft of Nordic countries than in military vehicles. Sweden has the JAS and Finland the F/A-18 while Norway and Denmark the F-16, which Norway has decided to replace with the F-35 and Denmark's decision on its future fighter aircraft is expected to arrive soon. As transport aircraft, Nordics have the C-130 Hercules, except Finland, which lacks that capability. Training aircraft choices are all different.

Table 6. Rotary-wing aircraft types and numbers in Nordic countries (Military Balance 2014)

\begin{tabular}{|c|c|c|c|c|c|}
\hline $\begin{array}{l}\text { Helicopte } \\
\mathrm{r}\end{array}$ & FIN & NOR & SWE & DEN & $\underset{\mathrm{n}}{\text { Commo }}$ \\
\hline $\mathrm{MRH}$ & $\begin{array}{l}\text { Hughes } \\
500 \mathrm{D} / \mathrm{E} \\
\text { (7) }\end{array}$ & $\begin{array}{l}\text { Bell } \\
412 \mathrm{HP} / \mathrm{SP} \\
(18)\end{array}$ & - & $\begin{array}{l}\text { AS550 } \\
\text { Fennec (8) }\end{array}$ & $0 / 33$ \\
\hline TPT & $\begin{array}{l}\text { NH90 } \\
\text { TTH } \\
(16)\end{array}$ & - & $\begin{array}{l}\text { AW109 (20); UH- } \\
60 \mathrm{M}(15) ; \text { NH90 TTH } \\
\text { (7); AS332 Super } \\
\text { Puma (9) }\end{array}$ & AW101 (6) & $23 / 33$ \\
\hline SAR & - & $\begin{array}{l}\text { Sea King } \\
\text { Mk43B (12) }\end{array}$ & - & AW101 (8) & $0 / 36$ \\
\hline ASW & - & $\begin{array}{l}\text { Lynx Mk86 } \\
\text { (5); NH90 } \\
\text { NFH (3) }\end{array}$ & - & $\begin{array}{l}\text { Super } \\
\text { Lynx } \\
\text { Mk90B (7) }\end{array}$ & $15 / 15$ \\
\hline
\end{tabular}

Helicopter types in the Nordic countries are shown in Table 6. The Nordic cooperation in helicopter purchases resulted in NH90 deals in Finland, Norway and Sweden while Denmark pulled out of the consortium. However, Norway has a different version of the NH90 and uses it in an anti-submarine role not foreseen by Finland and Sweden. Apart from that, there is no common helicopter equipment between the Nordic countries.

\section{What does this mean, in terms of possibilities for cost savings?}

So far, the assessment has been somewhat qualitative. However, it is possible to make some kind of a rough relative assessment of the different equipment types potential. Table 7 shows equipment types and numbers in Nordic countries for artillery. 
Table 7. Artillery types in Nordic countries. Numbers in parentheses (Military Balance 2014)

\begin{tabular}{|l|l|l|l|l|l|}
\hline Artillery & FIN & NOR & SWE & DEN & Common \\
\hline $\begin{array}{l}\text { Self- } \\
\text { propelled }\end{array}$ & 2S1 122mm (36) & $\begin{array}{l}\text { M109 } \\
155 \mathrm{~mm} \\
(18)\end{array}$ & $\begin{array}{l}\text { Archer } \\
155 \mathrm{~mm}(4)\end{array}$ & $\begin{array}{l}\text { M109 } \\
155 \mathrm{~mm} \\
(24)\end{array}$ & $42 / 82$ \\
\hline Towed & $\begin{array}{l}122 \mathrm{~mm}(234) ; \\
130 \mathrm{~mm} \\
(36) ; 155 \mathrm{~mm}(54)\end{array}$ & - & - & - & $0 / 324$ \\
\hline MRL & $\begin{array}{l}\text { M270 MLRS } \\
(22)\end{array}$ & - & - & $\begin{array}{l}\text { M270 } \\
\text { MLRS (12) }\end{array}$ & $34 / 34$ \\
\hline Mortar & $\begin{array}{l}\text { KRH 92 120mm } \\
(261) ; \text { XA-361 } \\
\text { AMOS (4) }\end{array}$ & - & $\begin{array}{l}\text { 120mm } \\
(191)\end{array}$ & $\begin{array}{l}\text { Soltam } \\
\text { K6B1 } \\
120 \mathrm{~mm} \\
(20)\end{array}$ & $0 / 662$ \\
& & & & & \\
\hline
\end{tabular}

Pugh (2012) provides data that enables the median cost to be calculated for various kinds of military equipment. He gives median unit price figures in $£$ for 2006 and the value is the median for new equipment (in-service date) as of 2006. For artillery, the median value for a new self-propelled gun is $2.56 \mathrm{M} / \mathrm{pcs}$, for towed field artillery $1.2 \mathrm{M} / \mathrm{pcs}$, for mortars $0.504 \mathrm{M} / \mathrm{pcs}$, and for multiple-rocket launchers (MRL) $10.15 \mathrm{M} / \mathrm{pcs}$. These values can be used as weights in order to obtain an overall value-based share of common equipment types. This is done in Table 8, where the common equipment number and total equipment number of each artillery type from the last column of Table 7 are the first two columns. Both these are multiplied by Pugh's unit price for new equipment and with 2006 average GBP/EUR exchange rate 0.6817 in order to present them in 2006 euros . The result is the unit price weighted values by artillery type of the two last columns in Table 8. The value-weighted share of common artillery to all artillery from the two last

Table 8. Relative valuation of artillery types and their similarity in Nordic countries

\begin{tabular}{|l|r|l|l|r|r|}
\hline Artillery & $\begin{array}{l}\text { Common } \\
\text { pcs }\end{array}$ & $\begin{array}{l}\text { Total } \\
\text { pcs }\end{array}$ & $\begin{array}{l}\text { Unit price } \\
(\mathrm{M} €)\end{array}$ & $\begin{array}{l}\text { Common } \\
\text { price }(\mathrm{M} €)\end{array}$ & $\begin{array}{l}\text { Total price } \\
(\mathrm{M} €)\end{array}$ \\
\hline Self-propelled gun & 42 & 82 & 3,76 & 157.7 & 307.9 \\
\hline Towed field artillery & 0 & 324 & 1,76 & 0 & 570.3 \\
\hline MLR & 34 & 34 & 14,89 & 506.2 & 506.2 \\
\hline Mortars & 0 & 662 & 0,74 & 0 & 489.4 \\
\hline Total & 76 & 1,102 & & 664.0 & 1873.9 \\
\hline
\end{tabular}


column totals of Table 8 can be calculated as $35 \%$ while the unweighted share from Table 7 is $72 / 1102=7 \%$.

It is important to notice that the price column does not indicate actual costs or value, as the equipment could be below or above the median to start with; it could be new or old; and moreover, being purchased well after Pugh's in-service date or even as second-hand. However, it indicates how much replacement equipment would have cost in 2006 euros with the same number of new ones and may give some rough idea of maintenance costs when a life-cycle cost rule-of-thumb like 30:70 is applied.

In summary Table 9, the relative figures are calculated for each country individually and totals for both all and common equipment. Of the four classes, fixed-wing aircraft is dominant ( $71 \%$ of total) and inside that class, fighters amount for $84 \%$, so they are indeed a key area in targeting potential savings. Overall, the relative value of common equipment is $45 \%$ of the total, but that figure drops to only $22 \%$ if the similarity of F-16s in Norway and Denmark is excluded.

Table 9. Assessment of relative importance of different equipment types and their type similarities (in $2006 \mathrm{M} €$ )

\begin{tabular}{|l|r|r|r|r|r|r|r|}
\hline & \multicolumn{1}{|c|}{ FIN } & NOR & \multicolumn{1}{c|}{ SWE } & DEN & \multicolumn{1}{c|}{ Total } & Common & Share \\
\hline Vehicles & 3,057 & 1,350 & 3,366 & 1,265 & 9,038 & 3,057 & $84 \%$ \\
\hline Aircraft & 8,339 & 6,552 & 16,934 & 5,128 & 36,953 & 8,339 & $32 \%$ \\
\hline Helicopters & 547 & 2,228 & 475 & 1,204 & 4,453 & 547 & $45 \%$ \\
\hline Artillery & 1,229 & 205 & 157 & 283 & 1,873 & 664 & $35 \%$ \\
\hline
\end{tabular}

As Finland, Norway and Sweden are currently committed to different aircraft types and Denmark's decision remains open, it is rather obvious that any savings potential in terms of economics of scale in spares inventories and purchasing and maintenance work is much less than if the Nordic countries all had the same equipment. The same reasoning can be extended to helicopter fleets, albeit with the exception of the NH90, which was the result of the Nordic Standard Helicopter Programme. Navy ships are not included in the tables firstly for the simple reason that there are no shared ship hulls in the Nordic countries and secondly, one should take a closer look at the system level into the armaments and other systems, like fire control systems and main engines, in order to determine the potential of each 
individual system. That leaves the military vehicles as the only group studied here with substantial commonality in equipment types between Nordic countries.

\section{Conclusions}

If the argumentation for Nordic defence co-operation at the political level, which is often based on savings and effectiveness, is assumed to have raised expectations that such co-operation would also solve military budget problems, that seems not to be the case, at least, regarding materiel co-operation. In procurement, the potential through current, independent defence planning systems based on needs arising from each country's security situation and replacement needs, does not produce a significant amount of the same capability need within the same time-window and therefore any opportunity for co-operation is and is likely to remain rather small. In addition, the sources of cost savings in MOTS procurement prevalent in Nordic countries also are different and likely smaller than in the R\&D-based collaborative development of the major EU countries. For maintenance, where significant savings assume the same platforms, the differences with existing equipment between the Nordic countries appear to limit the scope of savings, the exception being land vehicles. For both procurement and maintenance, the single most important item for any savings potential through co-operation is fighter aircraft due to its cost. However, the current choices in Sweden, Norway and Finland are different while Denmark's future decision is open.

This does not mean that individual projects should not be pursued whenever there are savings to be found, but only that the overall gain appears to be rather limited. Accordingly, there will be promising cases for Nordic co-operation and individual success stories also in the future. Likewise, it is not at all clear that the Nordic setting would be a cost-efficient co-operation framework if other co-operation options with NATO countries exist.

In terms of savings potential, domestic actions, such as those mentioned in the Danish Defence Agreement, are likely to have a greater potential. The Gray (2009) report that reviewed UK acquisition comes up with a number of such domestic proposals to improve acquisition, including better management and controls, a more skilled acquisition workforce and even outsourcing acquisition in a government-owned, contractor-operated model. Instead of more buyer cooperation, the commission directive 2009/81/EC on defence procurement aims to 
increase competition and effectiveness in the European defence market, which in turn would translate to savings to the buyers, i.e. defence forces.

The use of pooling and sharing could offer more savings, such as Finland being able to use the tactical transport capability of other Nordic countries or Sweden sharing its submarine capability, but they touch national sovereignty and, furthermore, raise the question how the sharing would be financed and arranged, especially between non-aligned nations.

\section{References}

Arena, M.V., Blickstein, I., Younossi, O. and Grammich C. (2006). Why Has the Cost of Navy Ships Risen?: A Macroscopic Examination of the Trends in US Naval Ship Costs Over the Past Several Decades. Vol. 484. RAND Corporation, Santa Monica, CA.

Bertlman T. and Anclair, Å. (2013). International Defence Cooperation Efficiency, Solidarity, Sovereignty: Report from the Inquiry on Sweden's International Defence Co-operation, Fö 2013:B; Swedish ministry of Defence 2013, p. 32. Retrieved from http://www.government.se/reports/2014/10/international-defencecooperation---efficiency-solidarity-sovereignty

Bromley, M. and Wezeman, S. (2013). Current trends in the international arms trade and implications for Sweden, SIPRI. Retrieved 27.5.2015 from http://www.sipri.org/research/armaments/transfers/publications/other_publ/other\% 20publications/Current $\% 20$ trends $\% 20 \mathrm{in} \% 20$ the $\% 20$ international $\% 20$ arms $\% 20$ trad e\%20and\%20implications\%20for\%20Sweden.pdf p. 29

Bruun-Hanssen, H. (2015). Forsvarssjefens tale i OMS 12.januar 2015. Retrieved 22.5.2015 from

https://forsvaret.no/aktuelt_/ForsvaretDocuments/Forsvarssjefens $\% 20 \% \mathrm{C} 3 \% \mathrm{~A} 5$ rsta le\%202015.pdf

Capron, L, (1999). The long-term performance of horizontal acquisitions, Strategic Management Journal, Vol. 20, No. 11, pp 987-1018.

Danish Defence Forces. (2012). Nordic defence ministers' meeting in Skagen 5-6 Nov. Retrieved ed 27.5.2015 from http://www.fmn.dk/eng/news/Pages/NordicdefenceministersmeetinginSkagen.aspx EDA (2011). EDA's Pooling \& Sharing. Fact Sheet, European Defence Agency. Retrieved 3.4. 2015 from www.eda.europa.eu

EDA European Defence Agency. (2015). European Defence Data 2013. Retrieved 20.5.2015 from http://eda.europa.eu/docs/default-source/eda-publications/edadefence-data-2013_web, ISBN: 978-92-95075-27-6

European Commission (2015). Defence Procurement. Retrieved 9.9.2015 from $\mathrm{http} / /$ ec.europa.eu/growth/single-market/public-procurement/rulesimplementation/defence/index_en.htm 
The Finnish Defence Forces (2015). Main Tasks. Retrieved 13.9.2015 from http://www.puolustusvoimat.fi/

Finnish Ministry of Defence FMoD (2015). Puolustushallinnon materiaalipolitiikka (Materiel Policy of Ministry of Defence). Retrieved 27.5.2015 from http://www.defmin.fi/files/1831/materiaalipolitiikka.pdf

Forsvaret. (2014). Forsvarets årsrapport (Norwegian defence force annual report). Retrieved 20.5.2015 from https://forsvaret.no/aarsrapport

Forsvaret. (2015a). Forsvarets oppgaver. Retrieved 11.5.2015 from https://forsvaret.no/oppgaver

Forsvaret. (2015b). Overall Mission of the Danish Armed Forces. Retrieved 11.5.2015 from http://www2.forsvaret.dk/eng/About/mission/Pages/Mission.aspx

Forsvarsdepartementet (2014). Framtidige anskaffelser til Forsvaret (FAF) 2014-2022 (Future acquisitions for Defence Forces). Retrieved from https://forsvaret.no/ForsvaretDocuments/faf-norsk_2014-2022_utgitt-mars2014.pdf

Försvarsmakten (2013). Materielförsörjning - Försvarsmaktens planerade materielförsörjning 2014 - 2021 (Defence forces acquisition plan). Retrieved 22.5.2015 from http://www.forsvarsmakten.se/siteassets/4-om-myndigheten/vartarbetssatt/materielforsorjning/mp13_materielforsorjning_2014-2021.pdf

Försvarsmakten (2014). Försvarsmaktens Årsredovisning 2013 (Swedish defence force annual report), FMV - FSV - Grafisk produktion, Stockholm, Sweden.

Försvarsmakten. (2015). About the Swedish Armed Forces. Retrieved 11.5.2015 from http://www.forsvarsmakten.se/en/

German and Swedish Ministries of Defence (2010). Intensifying Military Cooperation in Europe - "Ghent Initiative". Berlin and Stockholm, German and Swedish MoD. Retrieved 27.5.2015

from http://www.europarl.europa.eu/meetdocs/2009_2014/documents/sede/dv/sede2605 11deseinitiative_/sede260511deseinitiative_en.pdf

Giegerich, B., and Nicoll, A. (2012). The struggle for value in European defence. Survival, Vol. 54 No.1, 53-82.

Gray, B. (2009). Review of Acquisition for the Secretary of State for Defence: An Independent Report. Ministry of Defence. P. 296.

Hagelin, B. (2006). 'Hardware Politics, "Hard Politics" or "Where, Politics?": Nordic Defence Equipment Co-operation in the EU Context', in The Nordic Countries and the European Security and Defence Policy, edited by Alyson J. K. Bailes, Gunilla Herolf and Bengt Sundelius, Oxford: Oxford University Press, pp. 167-184.

Hartley, K. (1983). NATO Arms Co-operation. Georg Allen \& Unwin, London.

Hartley. K. (2008). Collaboration and European Defence Industrial Policy, Defence and Peace Economics, Vol. 19(4), pp. 303-315.

Heuninckx, B. (2008). A primer to collaborative defence procurement in Europe: Troubles, achievements and prospects, Public Procurement Law Review, Vol. 17 No. 3, pp. 123-145. 
IHS Jane's Defence Weekly (2015). Denmark selects Piranha V, halts artillery buy. Retrieved 22.5.2015 from http://www.janes.com/article/51105/denmark-selectspiranha-v-halts-artillery-buy

Jones, G., Ryan, E. and Ritschel, J. (2014). Investigation into the Ratio of Operating and Support Costs to Life-Cycle Costs for DoD Weapon Systems, Defense ARJ, Vol. 21 No. 1: pp. 442-464.

Järvenpää, P. (2014). Nordic defense cooperation: NORDEFCO and beyond, in: Northern Security and Global Politics, Routledge, Oxon eds. Dahl, A-S. and Järvenpää, P., pp.137-154.

Kvalvik S. R. and Berg-Knutsen E. (2009). Cost-efficient operation of defence theoretical foundations (Kostnadseffektiv drift av Forsvaret - Teoretisk fundament), Forsvarests forskninsistitut report 00305, ISBN 978-82-464-1544-4.

Lehtonen, J-M. and Anteroinen, J. (2013). Cooperation in public purchasing - an armaments case, The 20th EurOMA conference, 7-12 June, Dublin, Ireland. Retrieved from http://www.euroma2013.org/

Lindberg (2015). Puolustusvoimien komentaja Lindbergin puhe 4.2.2015 (A speech by Defence Forces Commander Lindhberg). Retrieved 20.5.2015 from Keskisuomalainen http://www.ksml.fi/uutiset/keski-suomi/puolustusvoimienkomentaja-lindbergin-puhe/1980890

The Military Balance (2014). Chapter Four: Europe, The Military Balance, 114:1, 59160, DOI: $10.1080 / 04597222.2014 .871877$

NATO (2012). Smart Defence? Retrieved 3.1.2013 from http://www.nato.int/cps/en/natohq/topics_84268.htm

NORDEFCO (2013). The NORDEFCO $\bar{M} C C$ Action Plan 2014-17. Retrieved 29.5.2015 from http://www.nordefco.org/files/131111\%20AP14_17_FINAL.pdf

NORDEFCO (2015a). The Basics about NORDEFCO. Retrieved 29.5.2015 from www.nordefco.org

NORDEFCO (2015b). NORDEFCO Annual Report 2014. Retrieved 12.9.2015 from http://www.nordefco.org/Files/NORDEFCO_arsrapport_2014.pdf

Porter, M. E. (1979). How competitive forces shape strategy. Harvard Business Review, March-April, p. 137-145.

Pugh, P. (2102). Source Book of Defence Equipment Costs. Ed. David G. Pugh.

Saxi, H. L. (2011). Nordic Defence Cooperation After the Cold War, Oslo: Norwegian Defence University College (FHS), Norwegian Institute For Defence Studies (IFS). Retrieved 27.5.2015 from http://hdl.handle.net/11250/99336

SIPRI (2015). MILEX Database. Retrieved 11.5.2015 from http://www.sipri.org/research/armaments/milex/milex_database

Staples, M. (2013). The Future of European Defence: Tackling the Productivity Challenge, McKinsey \& Company. Retrieved 3.9.2013 from http://www.cfr.org/europe/mckinsey-future-european-defence-tacklingproductivity-challenge/p31216

Stevenson, W. (2011). Operations Management. McGraw-Hill/Irwin, 11th International Edition, New York, p. 908. 
Swedish Ministry of Defence (2015). Final reports on deepened defence cooperation between Finland and Sweden and International Defence Cooperation Efficiency, Solidarity, Sovereignty. $\quad$ Retrieved 4.6.2015 from http://www.regeringen.se/globalassets/regeringen/dokument/forsvarsdepartementet/ final-reports-on-deepened-defence-co-operation-between-finland-och-sweden.pdf

Søreide, I. E. (2014). Speech at Nordic Defence Industry Seminar, Sundvolden, 20.05.2014. Retrieved 29.4.2015 from https://www.regjeringen.no/nb/aktuelt/Speech-at-Nordic-Defence-IndustrySeminar-Sundvolden-May-20th-2014-/id760341/

United Nations Office for Disarmament Affairs UNODA (2015b). Transparency in Armaments - UN Standardized Instrument for Reporting Military Expenditures: Guidelines, Department for Disarmament Affairs United Nations, New York. Retrieved 20.5.2015 from http://www.un.org/disarmament/convarms/Milex/Docs/Forms/Guidelines/MILEX $\% 20$ publication\%20final\%20E.pdf

UNODA (2015a). United Nations Report on Military Expenditures. Retrieved 20.5.2015 from http://www.un-arm.org/Milex/Home.aspx

Valášek, T. (2011). Surviving Austerity: The case for a new approach to EU military collaboration. Centre for European Reform. 42 pages. Retrieved 15.5.2015 from http://www.cer.org.uk/sites/default/files/publications/attachments/pdf/2011/rp_981141.pdf 